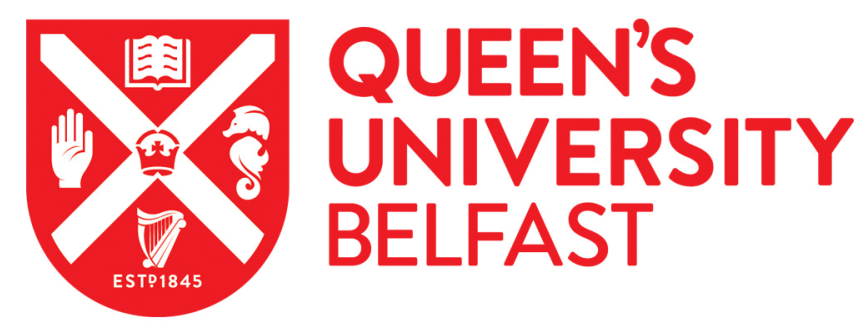

\title{
Okpabi and others v Royal Dutch Shell PIc and another [2021] UKSC 3
}

Hopkins, S., O'Kelly, C., Hackett, C., \& Patton, C. (2021). Okpabi and others v Royal Dutch Shell Plc and another [2021] UKSC 3. Northern Ireland Legal Quarterly, 72(1), 148-158.

https://doi.org/10.53386/nilq.v72i1.922

\section{Published in:}

Northern Ireland Legal Quarterly

\section{Document Version:}

Peer reviewed version

\section{Queen's University Belfast - Research Portal:}

Link to publication record in Queen's University Belfast Research Portal

\section{Publisher rights}

Copyright 2021, School of Law QUB.

This work is made available online in accordance with the publisher's policies. Please refer to any applicable terms of use of the publisher.

\section{General rights}

Copyright for the publications made accessible via the Queen's University Belfast Research Portal is retained by the author(s) and / or other copyright owners and it is a condition of accessing these publications that users recognise and abide by the legal requirements associated with these rights.

Take down policy

The Research Portal is Queen's institutional repository that provides access to Queen's research output. Every effort has been made to ensure that content in the Research Portal does not infringe any person's rights, or applicable UK laws. If you discover content in the Research Portal that you believe breaches copyright or violates any law, please contact openaccess@qub.ac.uk. 


\title{
Okpabi and others v Royal Dutch Shell Plc and another [2021] UKSC 3
}

\author{
Samantha Hopkins* Ciarán O'Kelly Ciara Hackett \\ Clare Patton \\ School of Law, Queen's University Belfast \\ ${ }^{*}$ Corresponding author: shopkins04@qub.ac.uk
}

01 March 2021

\begin{abstract}
Discussion of parent liability recognises the vast power and influence that parent companies wield both inside and outside their home jurisdictions, on the employees and host communities of subsidiaries, and supply chains alike. ${ }^{1}$ The ability of such power to manifest in negative impacts on these stakeholders has been a key concern of business and human rights legal scholarship. The increased number of high-profile judgments recognises both the importance of promoting enhanced accountability as well as ensuring redress for victims of corporate human rights impacts. Recently, judgments have begun to fall in favour of the victims rather than corporate defendants marking what may represent the emergence of a more victim centred approach to corporate liability. The issue of parental liability has been considered lately in the UK in the 'Holy Trinity' of cases; ${ }^{2}$ Chandler $v$ Cape plc ${ }^{3}$ and Vedanta Resources plc and Another $v$ Lungowe and Others. ${ }^{4}$ Okpabi is the most recent decision in this area and in reaffirming and extending the decision in Vedanta offers a new departure of parental liability summary judgments going forward.

Vedanta and Okpabi are closely linked. In both cases, the direct actions of a subsidiary company of a UK parent were alleged to have caused environmental harms - namely oil spills, which negatively affected communities in Zambia and Nigeria respectively. Given the existence of both subsidiary and (high-profile) parent companies in the two cases, a key issue was whether a duty of care was owed by the parent company to victims on
\end{abstract}

\footnotetext{
${ }^{1}$ John Ruggie, Just Business: Multinational Corporations and Human Rights (W W Norton 2013) 96.

${ }^{2}$ Tara Van Ho, 'On Emissaries and Control: Corporate Accountability in the Aftermath of the Shell litigation in the UK and the Netherlands' (Rapid Response Event $19^{\text {th }}$ Feb 2021) $<$ https://www.youtube.com/watch?v=iq7YwPNMafA\&feature=youtu.be $>$ Accessed 25 Feb 2021 ${ }^{3}[2012\}$ EWCA Civ 525

${ }^{4}[2019]$ UKSC 20
} 
behalf of its subsidiary. ${ }^{5}$ It was found in both instances that a duty of care was owed by the parent company to the victims. In both Vedanta and Okpabi, ${ }^{6}$ the issue of duty of care was merely a preliminary procedural issue (discussed within the jurisdictional hearing) prior to later consideration of the facts.

On this note, Vedanta was never heard on the facts, as it was settled in January $2021 .^{7}$ However, the procedural issues discussed in that case, given that Okpabi was stayed until the former had been heard in the UK Supreme Court, were of significance in the later judgment and so form a discussion point in both the Okpabi decision and this comment. Indeed, Lord Hamblen, who gave the unanimous judgment in Okpabi, stated that it might reasonably have been expected that the guidance provided by [Vedanta] would resolve this appeal without the need for a hearing[, although that] proved not to be the case' ${ }^{8}$ Many of the issues covered here are, due to the timing of the two UKSC appeals, similar to ones raised in Vedanta, however, there are some novel points of interest which we consider below.

There are also two general procedural points to note. First, this case was able to proceed in the UK courts even though the alleged impact took place in Nigeria. This was because art. 4(1) of the Recast Brussels Regulation was held by the Court of Justice in Osuwu $v$ Jackson to allow any claimant to sue an English domiciled defendant in England free from jurisdictional challenge on forum non conveniens grounds. ${ }^{9}$ Second, the unanimous judgment was delivered on behalf of four judges even though five had heard the appeal in June 2020. This was due to the subsequent illness of Lord Kitchin. Lord Hodge gave a direction under section 43(3) of the Constitutional Reform Act 2005 that the court was still constituted by the remaining four Justices. ${ }^{10}$

\section{Facts and procedural history}

Okpabi was, like Vedanta, a jurisdiction appeal, rather than a discussion of the merits of the case itself. The facts of the cases were also similar. In Vedanta, 1,826 Zambian

\footnotetext{
${ }^{5}$ In the Dutch courts a similar decision was reached in Four Nigerian Farmers and Milieudefensie $v$ Shell, albeit this was decided on the merits of the case, not at the procedural stage, and as such can be distinguished from the Okpabi decision. Case/C/09/337050/HA ZA 09- 1580 (ECLI: NL: GHDHA : 2021: 134 (tr. Available <https://uitspraken.rechtspraak.nl/inziendocument?id=ECLI:NL:GHDHA:2021:134> ) accessed 17 February 2021

${ }^{6}$ Okpabi and others $v$ Royal Dutch Shell Plc and another [2021] UKSC 3

${ }^{7}$ 'Vedanta \& Konkola Copper Mines settle UK lawsuit brought by Zambian villagers for alleged pollution from mining activities' (Leigh Day, 19 January 2021) <https://www.businesshumanrights.org/en/latest-news/vedanta-konkola-copper-mines-settle-uk-lawsuit-brought-byzambian-villagers-for-alleged-pollution-from-mining-activities/> Accessed 17 February 2021

${ }^{8}$ Okpabi (n 6) Para 2

${ }^{9}$ Case C-281/02 [2005] QB 801 as cited in James Beeton, Supreme Court Rules in Okpabi v Royal Dutch Shell PLC and SPDC (International and Travel Law Blog, 12 February 2021) <https://internationalandtravellawblog.com/2021/02/12/supreme-court-rules-in-okpabiv-royal-dutch-shell-plc-and-spdc/> accessed 22 February 2021. It will be interesting to see whether the UK's departure from the EU will lead to any changes in this area going forward.

${ }^{10}$ (n 6) Para 161
} 
villagers brought a claim against Vedanta and Konkola Copper Mines plc, its Zambian subsidiary, related to toxic emissions from KCM's Nchanga Copper mine into water used for drinking and irrigation. In Okpabi, 42,335 Nigerian citizens 'allege that numerous oil spills... have caused widespread... water and ground contamination' affecting safe water usage in their communities for 'drinking, fishing, agricultural, washing or recreational purposes. ${ }^{11}$ The first defendant was The Shell Petroleum Development Company of Nigeria Ltd (SPDC), a Nigerian registered company, as part of a joint venture with the state-owed Nigerian National Petroleum Corporation (NNPC) and two other companies (where SPDC owns 30\%, and NNPC owns 55\%). ${ }^{12}$ The second defendant was Royal Dutch Shell (RDS), the parent company of SPDC domiciled in the UK.

It was argued that RDS owed a common law duty of care to the claimants as it 'exercised significant control over [or assumed responsibility for] material aspects of SPDC's operations [through] the promulgation and imposition of mandatory health, safety and environmental policies, standards and manuals' which were insufficient to protect the claimants from 'harm arising from SPDC's operations'. ${ }^{13}$ It was also claimed that SPDC is liable on an individual basis. ${ }^{14}$ Evidently, given the Nigerian registration of SPDC, this latter would be impossible unless certain circumstances are met by the parent/subsidiary relationship.

The key question, in this case, concerned the jurisdictional 'gateway' test in paragraph 3.1(3) of Practice Direction 6B. ${ }^{15}$ This states that 'appellants must establish that their claims against the anchor defendant [RDS] raise a real issue to be tried, which means that they have a real prospect of success'. The question was twofold: first, it was asked whether there is an arguable case for a duty of care being owed by RDS. This grounded the second issue, which was whether SPDC is a 'necessary or proper party' to the claim that RDS owed a duty of care, which would allow UK jurisdiction to be granted for the foreign subsidiary. ${ }^{16}$

Such jurisdiction was granted by HHJ Raeside QC in 2016, before being challenged by RDS and SPDC. It was held, in the Technology and Construction Court in 2017, that it was 'not reasonably arguable that there is any duty of care upon RDS.' ${ }^{17}$ As such, SPDC was held not to be a 'necessary or proper party' to the claim, and jurisdiction was rescinded. This was again appealed and heard at the Court of Appeal in 2018. ${ }^{18}$ The Court of Appeal considered that the approach to the evidence was in error in certain respects and therefore re-examined it (which was raised in this case as itself in error, discussed below). It was held (with Sales LJ dissenting ${ }^{19}$ ) based on the evidence that

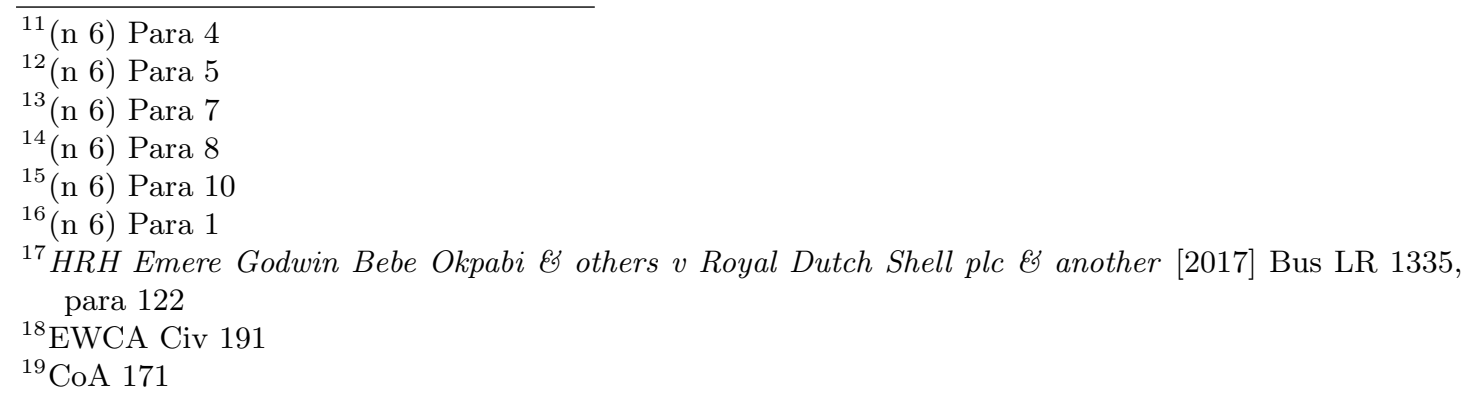


there was 'no arguable case' that RDS owed a duty of care in these circumstances. ${ }^{20}$ Permission to appeal was once again granted after the conclusion of Vedanta, given the impacts which it promised on this case.

\section{Issues of Law}

The core question, in this case, was whether the Court of Appeal had materially erred in law in several aspects - especially in light of the Vedanta decision. These concerned the procedure used in determining the existence of an 'arguable claim' against RDS, the interpretation of principle of duty of care relating to parent company liability, and how such duty of care was (or rather was not) found. If they were found to have erred, the question then became "whether the majority was wrong to decide that there was no real issue to be tried. ${ }^{21}$

Prior to these, however, the issue of proportionality was briefly considered - essentially reiterating the decision in Vedanta, where it had been a more prominent issue. ${ }^{22}$ The importance of avoiding mini-trials at the procedural stage ${ }^{23}$ was emphasised in both cases: as in Vedanta, with 8,000 pages of documents, there were 2,000 pages and eight files of exhibits submitted here, ${ }^{24}$ which was considered excessive in both instances. Instead, it was argued, the focus should remain on whether, based on the particulars of claim, there is a 'real prospect of success' ${ }^{25}$ for the cause of action.

The first element in a 'real prospect for success' was whether the procedure used in determining the existence of an 'arguable claim' against RDS was appropriate. It was found, for a variety of reasons, that it was not so. The Court of Appeal was 'drawn into conducting a mini-trial' contrary to Three Rivers and the later affirmation in Vedanta. ${ }^{26}$ Given the aforementioned plethora of documentation submitted, the Court of Appeal was 'drawn into an evaluation of the weight of the evidence and the exercise of a judgment based on that evidence' instead of focusing on whether an arguable claim exists. ${ }^{27}$ This led to 'the court making inappropriate determinations ${ }^{28}$ concerning both the factual and documentary evidence which were 'not appropriate on an interlocutory application.' 29

In contrast, Sales LJ in the Court of Appeal dissent had stated that certain factual evidence of a witness 'goes some way to show that there is a very real prospect that highly relevant documents, which may well be supportive of the claimants' case, will be forthcoming on disclosure if the action proceeds, ${ }^{, 30}$ which was the intended purpose of

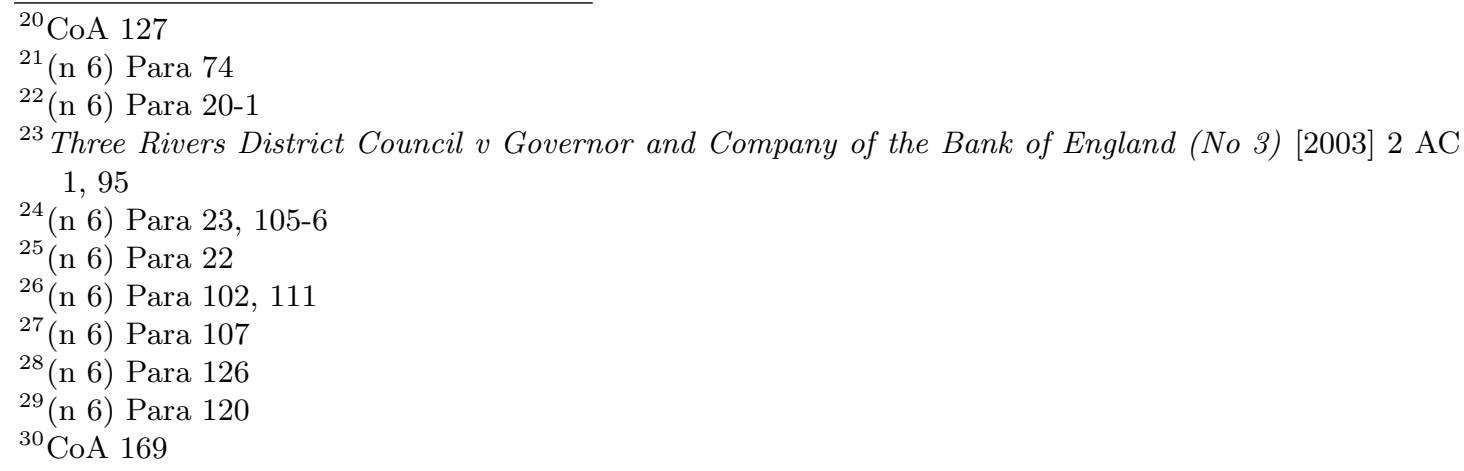


that factual evidence. Essentially, the procedural evidence was to be used (and was not used) as a mere demonstration that further evidence could be forthcoming after disclosure was required. This was supported by Lord Briggs in Vedanta: 'the court cannot ignore reasonable grounds which may be disclosed at the summary judgment stage for believing that a fuller investigation of the facts may add to or alter the evidence relevant to the issue. '31 'In other words,' as Lord Hamblen put it in Okpabi, 'are there reasonable grounds for believing that disclosure may materially add to or alter the evidence relevant to whether the claim has a real prospect of success? ${ }^{32}$ All such determinations recognise the importance of internal corporate documentation (such documentation being minimal of necessity in the present instance). ${ }^{33}$

Second, it was considered that the principles of duty of care as it relates to parent liability were incorrectly interpreted for three key reasons. Firstly, there was an inappropriate focus' on the issue of control (by RDS over the subsidiary SPDC). ${ }^{34}$ While this was a significant aspect of the Court of Appeal decision, here it was held that 'control is just a starting point ${ }^{\prime 35}$ for any such decision. Instead what is important is the extent to which any management processes were or were not shared.

To this end, it was clarified that 'control' and 'de facto management' of an activity are 'two different things. A subsidiary may maintain de jure control of its activities, but nonetheless, delegate de facto management of part of them to emissaries of its parent. ${ }^{36}$ This was a point raised in Vedanta, where Lord Briggs stated that a duty of care may be found if a parent 'holds itself out as exercising that degree of supervision and control of its subsidiaries, even if it does not, in fact, do so. ${ }^{37}$ Control is, therefore, less relevant than the parent's public statements holding itself out as exercising a 'degree of supervision and control ${ }^{38}$ of its subsidiary's operations. Secondly, the Court of Appeal indicated that groupwide policies or standards are insufficient to indicate a duty of care on the part of the parent, ${ }^{39}$ which was a submission rejected in Vedanta. In that case, Lord Briggs stated that he did not consider there to be 'any such reliable limiting principle', since group guidelines, if possessed of 'systemic errors' ${ }^{40}$ may in implementation

${ }^{33}$ This has been found previously in Lubbe v Cape plc [2000] 1 WLR 1545, para 1555; in Hardie Industries plc v White [2018] NZCA 580; in Vedanta citing Tesco Stores Ltd v Mastercard Inc [2015] EWHC $1145(\mathrm{Ch})$, para 73; and in Vedanta at para 44. For critique of the CoA judgment on this point, see Okpabi at para 133-134. - In criticizing the CoA on this, the Supreme Court is aligning itself with international and comparative jurisprudence such as in Hardie Industries plc $v$ White [2018] NZCA 580. For more see Ekaterina Aristova and Carlos Lopez, 'UK Okpabi et al v Shell: UK Supreme Court reaffirms parent companies my owe a duty of care towards communities impacted by their subsidiaries in third countries' (Opinio Juris, 16 February 21) http://opiniojuris.org/2021/02/16/ukokpabi-et-al-v-shell-uk-supreme-court-reaffirms-parent-companies-may-owe-a-duty-of-care-towardscommunities-impacted-by-their-subsidiaries-in-third-countries/ accessed 22 February 2021

${ }^{34}$ (n 6) Para 146

35 (n 6) Para 147

${ }^{36}$ (n 6) Para 147 - the use of 'emissaries' here is of interest.

${ }^{37}$ (n 4$) 53$

${ }^{38}$ Lord Briggs in Vedanta UKSC 53, cited in Okpabi para 148.

${ }^{39}$ (n 6) Para 143

${ }^{40}$ Although these are not pleaded in the present case, para 153.
} 
'cause harm to third parties. ${ }^{41}$ Thirdly, and overall, it was recognised, as per Vedanta and $A A A v$ Unilever $p l c,{ }^{42}$ that 'there is nothing special or conclusive about the bare parent/subsidiary relationship'. ${ }^{43}$ Essentially, the mere existence of a parent/subsidiary relationship is insufficient either to demonstrate a lack of duty of care or the existence of a duty of care.

Third, the means of determining duty of care in parent liability cases, including reliance on the Caparo test, ${ }^{44}$ was questioned. ${ }^{45}$ Since, as per Vedanta, parent liability is not a novel category of duty, there was no need to apply the Caparo test in either case. ${ }^{46}$ As such, the examination of proximity and whether a duty was 'fair, just and reasonable' was unnecessary. ${ }^{47}$ Instead, any contested duty of care should consider 'management/joint management of the relevant activity', provision of advice or policies, 'promulgati[on of] groupwide policies and... active steps to ensure their implementation', and the parent 'holding out that it exercises a particular degree of supervision and control' over the subsidiary. ${ }^{\prime 48}$ In this instance, it was also argued that RDS possessed detailed knowledge of past and potential spills, and well as superior expertise in health and safety issues. ${ }^{49}$ It was agreed that these are the appropriate means of determining a duty of care where the parent/subsidiary relationship is concerned.

Having clarified the above areas of error at the Court of Appeal, the question then became whether there was any real issue to be tried, as per paragraph 3.1(3) Practice Direction 6B ('appellants must establish that their claims against the anchor defendant [RDS] raise a real issue to be tried, which means that they have a real prospect of success'). This was found to be so, in light of 'the case set out in the pleadings, fortified by the points made in reliance upon the RDS Control Framework and the RDS HSSE Control Framework', ${ }^{50}$ as well as the prospect of future submitted relevant disclosure. ${ }^{51}$ Given how RDS' organisational structure operates in practice, as well as the weights of various types of disclosure, are disputed in the present case, Lord Hamblen suggests that these issues be disputed at trial. ${ }^{52}$

\section{Analysis}

There are several points of interest arising from this case, despite its considerable reliance upon the prior Vedanta decision. First, the conclusive rejection of mini trials for jurisdictional issues limits the ability of companies to utilise preliminary challenges to

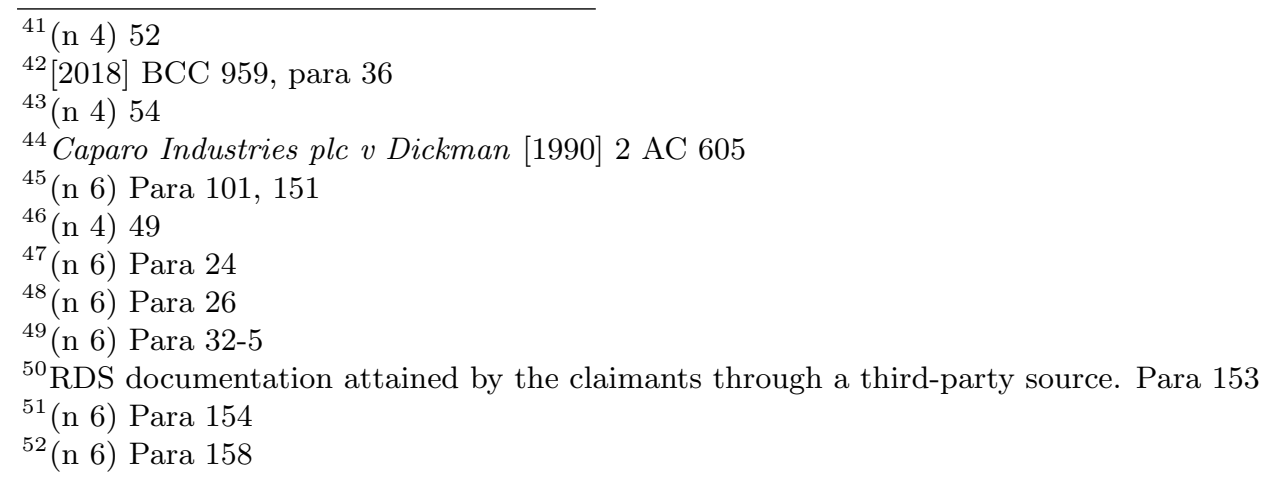


avoid liability for their human rights abuses. The conclusive emphasis on procedural issues to the exclusion of such fact-based determinations means that submission, and consideration, of large quantities of documents, is less plausible as an approach to delay hearings.

Relatedly, the importance of documentation was again emphasised in this case - while there was no disclosure of such documentation in this case, the court recognised that the acquisition of a variety of organisational documents would be vital to any concrete determination of duty of care. Therefore, where documentation is relevant to the issue under consideration (i.e. not a jurisdictional, procedural issue), it will play a significant role in the decision to allow a case to proceed to trial. This raises the further question of the weightings of various evidence and documentation, which was decided in neither Vedanta nor this case (given the irrelevance of such documentation to the procedural issue under consideration). Should this case proceed to a trial on the question of fact, this would be a worthwhile discovery for future law.

Second, the recognition that "control is just a starting point ${ }^{\prime 53}$ has considerable implications for the ability of such procedural cases, in the absence of excessive documentation, to fall in the claimants' favour. It prevents the application of a strict reading to the decision, considering issues such as the extent to which management of an activity is shared. This will place a much lower evidentiary burden on claimants at the preliminary stage, allowing more cases to be considered on their merits than has been the case in the past. This, therefore, is likely to increase the potential for access to justice for those victims affected by actions of multinational operating through a subsidiary. Such a move has been described as creating 'some degree of equality of arms' for victims, ${ }^{54}$ by 'lowering the bar (in a good way)' for accessing the courts. ${ }^{55}$ Further, we can now assume that the summary trial will hitherto be very limited in cases surrounding parent/subsidiary liability.

Beyond, Okpabi can be distinguished from Vedanta in its discussion of corporate group structures. For example, at paragraph 51. Lord Hamblen notes, '[i]t is the appellants' case that the Shell group's vertical organisational structure means that it is comparable to Lord Briggs' example of group businesses which "are, in management terms, carried on as if they were a single commercial undertaking, with boundaries of legal personality and ownership within the group becoming irrelevant". 56

Further, the weight placed on 'emissaries' and the relationship between control and management, in many ways seemed to point to potential problems with corporate group structures as flagged previously by Hadden. ${ }^{57}$ As Hadden argues concerning taxationmanagement and group structures, the complex corporate structures that have emerged

\footnotetext{
${ }^{53}$ (n 6) Para 147

${ }^{54}$ Ekaterina Aristova and Carlos Lopez (n 33)

${ }^{55}$ Lucas Roorda, 'Lowering the Bar (in a good way): The Supreme Court decision in Okpabi v Shell' (Rights as Usual Blog, 17 February 2021) <https://rightsasusual.com/?p=1395> Accessed $22^{\text {nd }}$ February 2021

${ }^{56}$ (n 6) Para 157

${ }^{57}$ Tom Hadden, 'Accountable Governance in Corporate Groups: The Interrelationship of Law and Accounting' (2012) 22 Australian Accounting Rev. 117, 119.
} 
are designed around management of financial and tort liabilities, but do not map cleanly onto management pathways. "Within most large multinationals," Hadden writes, "the structures for managerial decision making are based on functional or product divisions that are typically superimposed upon, and often cut across, the formal legal structures." 58 Managerial structures are often 'more rational' and 'centralised' than would be possible if management was assigned by discrete corporate entity. That this is the case provides an answer of sorts to Chancellor Sir Geoffrey Vos's remark in the Court of Appeal that "it would be surprising if a parent company were to go to the trouble of establishing a network of overseas subsidiaries with their own management structures if it intended itself to assume responsibility for the operations of each of those subsidiaries." 59 Corporate groups aim at limiting the liabilities of parent companies, not necessarily to act independently of them. ${ }^{60}$

A further problem may manifest in the corporation accepting responsibility for subsidiary management. Notably, from both Okpabi and Vedanta, if a company 'holds itself out' as managing a subsidiary, it is likely to be considered so responsible; if it omits to reference any such management it is likely to be considered otherwise. ${ }^{61}$ This, therefore, has implications for voluntary reporting by corporations; reinforcing the point taken from Vedanta to the effect that this could prompt a withdrawal of responsibility by parent companies, rather than committing to either perspective. ${ }^{62}$ The corporate reporting landscape may be too multifaceted for parent companies to simply withdraw from or withhold on commitments. Reporting has long since been a useful tool for corporations in managing reputational risk through, for example, the UN Global Compact. ${ }^{63}$ Beyond, the trend within the corporate reporting space is more reporting, not less, with requirements from the UN Guiding Principles on Business and Human Rights, ${ }^{64}$ disclosure requirements (e.g. Modern Slavery Act 2015 (UK), California Supply Chains Transparency Act), ${ }^{65}$ and due diligence obligations (e.g. Devoir de vigilance des sociétés

\footnotetext{
${ }^{58}$ Ibid, 118.

${ }^{59}$ EWCA Civ 191, 196

${ }^{60}$ See Dine J, The Governance of Corporate Groups (Cambridge University Press 2000); Muchlinski P, 'The Changing Face of Transnational Business Governance: Private Corporate Law Liability and Accountability of Transnational Groups in a Post-Financial Crisis World' (2011) 18 Indiana Journal of Global Legal Studies 665; Muchlinski P, 'Limited Liability and Multinational Enterprises: A Case for Reform?' (2010) 34 Cambridge Journal of Economics 915.

${ }^{61}$ (n 6) Para 148; (n 4) 53

${ }^{62}$ Samantha Hopkins, 'Vedanta Resources Plc and Another v Lungowe and Others [2019] UKSC 20' (2019) 70(3) NILQ 371, 375.

${ }^{63}$ Communications on Progress, UN Global Compact <https://www.unglobalcompact.org/participation/ report>

${ }^{64}$ Principle 15 (b) and Principle 17, United Nations, Guiding Principles on Business and Human Rights (OHCHR 2011)

${ }^{65}$ Modern Slavery Act 2015. For discussion see: Virginia Mantouvalou, 'The UK Modern Slavery Act 2015 Three Years On.' (2018) 81 (6) The Modern Law Review 1017-1045; Genevieve LeBaron, and Andreas Rühmkorf, 'The domestic politics of corporate accountability legislation: struggles over the 2015 UK Modern Slavery Act.' (2019) 17(3) Socio-Economic Review 709-743. For the reporting requirements see, Modern Slavery Act 2015 (Transparency in Supply Chains) Regulations 2015, reg. 2. These reporting mechanisms are in addition to those set out in relevant Company Law legislation (e.g., s 415 and s172 Company Act 2007)
} 
mères et des entreprises donneuses d'ordre (France), The Netherlands' Child Labour Due Diligence Law, ${ }^{66}$ and the EU Conflict Minerals Regulation) ${ }^{67}$ With recent proposals such as the European Parliament mandatory human rights due diligence (mHRDD) 68 and the German (draft) Supply Chain Due Diligence Act, ${ }^{69}$ withdrawing from responsibilities as a result of the Okpabi decision, would raise questions about corporations' aspirations to respecting human rights.

Finally, and perhaps less optimistically, although this procedural issue was ruled in favour of the claimants, there were other jurisdictional issues not addressed by the trial judge which will likely be remitted by RDS and SPDC. ${ }^{70}$ In the previous case, the claimants succeeded based largely on the lack of 'substantial justice' which would be attained were the case heard in Zambia (one of the poorest countries in the world ${ }^{71}$ ). In this case, the issues of appropriate forum for the case and access to justice were not relevant. If these issues were to be raised here, it could preclude the case from being heard in this jurisdiction. The competing arguments of Shell that a fair trial is possible in Nigeria, whilst on the other filing ISDS claims arguing that Nigerian courts have been unfair to them suggests that jurisdictional issues (after their defeat in the Dutch Courts on the merits of similar case) will continue to shape this type of case in the future. ${ }^{72}$ Indeed, there is the possibility, given the settling of Vedanta before it reached a full hearing, that this case will be similarly dealt with, however, this is yet to be seen.

Overall, this is a clear affirmation and extension of the precedent set out in Vedanta. This, along with the recent Milieudefensie decision in the Netherlands, ${ }^{73}$ is a clear step away from previous parent liability decisions such as Jesner et al $v$ Arab Bank plc ${ }^{74}$ and $A A A v$ Unilever plc. While these had decided in favour of the defendant companies, this trend would appear to be being reversed in certain circumstances. It is to be hoped that case law continues in the present trajectory.

California Transparency in Supply Chains Act (2010). Also of relevance here is, s.1502 Wall Street Reform and Consumer Protection Act (2010).

${ }^{66}$ Dutch Child Labour Due Diligence Bill

${ }^{67}$ EU Regulation 2017/821

${ }^{68}$ Lara Wolters (Rapporteur) Draft Report with recommendations to the Commission on corporate due diligence and corporate accountability, Committee on Legal Affairs (2020/2129(INL) <https://www.europarl.europa.eu/doceo/document/JURI-PR-657191_EN.pdf > Report adapted by the European Parliament Legal Committee on the $27^{\text {th }}$ January 2021.

${ }^{69}$ Robert Grabosch, 'The German Supply Chain Due Diligence Act in the Making - What to Expect' (NOVABHRE Blog, 15 February 2021) <https://novabhre.novalaw.unl.pt/german-supply-chain-duedligence-act-what-to-expect/> accessed 22 February 2021

${ }^{70}$ (n 6) Para 160

${ }^{71}$ (n 4) 90

${ }^{72}$ E.g. Shell files arbitration claim against Nigeria over spill dispute (The Star, 14 February 2021) <https://www.bilaterals.org/?shell-files-arbitration-claim> Accessed 22 February 2021; Four Nigerian Farmers and Milieudefensie $v$ Shell Case/C/09/337050/HA ZA 09- 1580 (ECLI: NL: GHDHA : 2021: 134 (tr. Available <https://uitspraken.rechtspraak.nl/inziendocument?id=ECLI:NL:GHDHA:2021:134> ) accessed 17 February 2021

${ }^{73}$ Four Nigerian Farmers and Milieudefensie v Shell id.

${ }^{74}$ No. 16-499, 584 U.S. --- (2018) 